Max-Planck-Institut für demografische Forschung

Max Planck Institute for Demographic Research

Konrad-Zuse-Strasse 1 - D-18057 Rostock · GERMANY

Tel +49 (0) 3812081 - 0; Fax +49 (0) 3812081 - 202;

http://www.demogr.mpg.de

MPIDR WORKING PAPER WP 2007-007

FEBRUARY 2007

\title{
Social construction of neglect: the case of unaccompanied minors from Morocco to Spain
}

Núria Empez Vidal (empez@demogr.mpg.de)

This working paper has been approved for release by: Gerda Ruth Neyer (neyer@ demogr.mpg.de) Deputy Head of the Laboratory of Contemporary European Fertility and Family Dynamics.

(C) Copyright is held by the authors.

Working papers of the Max Planck Institute for Demographic Research receive only limited review. Views or opinions expressed in working papers are attributable to the authors and do not necessarily reflect those of the Institute. 


\title{
Social Construction of Neglect: The Case of Unaccompanied Minors from Morocco to Spain
}

\author{
Núria Empez Vidal \\ PhD Student, Max Planck Institute for Demographic Research
}

February 2007

"If they opened the border between Tangier and Spain for just four hours, only the cripples would remain" (R., young worker in a British manufacturing company in Tangier).

\section{Introduction}

One of the most riveting sets of images in the international press in the last decade has been the arrival of young North African boys who cross the Straits of Gibraltar trying to reach the shores of southern Spain. Most have been Moroccans, coming by hiding under trucks or buses on ferries from Tangier, in northern Morocco, or in overloaded "pateras," small, precarious speed boats run by professional smugglers. The Spanish press has sometimes portrayed such boys sympathetically. Most of the media, however, has pointed to the economic burden that Spain takes on, mixed with a sense of panic. Here are some recent examples:

"The arrival of Moroccan minors without family overwhelms the Generalitat (Catalan Government)". (La Vanguardia $04 / 07 / 2005)$

"Morocco continues to pour minors into Melilla". (Paz Dijital 26/06/2006) 
These boys have frequently been met by rejection if not violence by Spanish authorities. Most are sent back immediately, never making it beyond the port in Spain. Those few who make it past the port must enter the Spanish child protection system in order to stay; once in Spain, some of them face institutional mistreatment under the Spanish child protection system. Not surprisingly, many of them turn instead to petty crime to subsist or to drugs, ending up in the street or in jail. Those who are sent back to Morocco face the possibility of both police violence when they arrive and of rejection by their families for having failed to stay in Spain.

Seeing these boys appearing under such dire circumstances, the world press reacted in shock and disbelief: How could this happen in a civil European society in this day and age? Since the time when these boys first began appearing in the 1990s, their plight has commanded international attention from policy makers and humanitarian rights groups as well as scholars ${ }^{1}$ and journalists. Children are not only legal minors, but by any measure of international law, they are the most vulnerable of persons. In the present case, they are also unaccompanied. International humanitarian conventions view children lacking the care and supervision of an adult as "neglected," a status that, irrespective of their nationality or circumstances, should accord them immediate protection in whatever state they arrive. Concern for the welfare of children, particularly neglected ones, is one of the strongest values in contemporary Europe as well as in UN and humanitarian law. No other group draws as much worry. Why, then, do Moroccan boys arrive like this, and why do so many of them end up in such perilous circumstances, either in Spain or back in Morocco?

Hidden from the sensational headlines have been two things: the pressures back home that have moved these boys to come, and reports of how they have fared in Spain. At the center of the dilemma is the notion of "neglect." Different factors could precipitate situations of what appears to be child neglect: one in which children's basic physical and emotional needs are disregarded, and the other in which a child's future prospects for success are not encouraged or invested in. In either case, neglect may be applied to all siblings; in other cases, specific children may become the targets of

\footnotetext{
${ }^{1}$ Most of the literature and findings on unaccompanied minors - Capdevila (2003), Con Red (2005), Empez (2005), Jimenez (2004), UNICEF (2005) - is about boys, though there also exist social networks for girls who come to be fostered by families in Europe and who quickly become invisible subjects in the unaccompanied minors migratory phenomenon.
} 
exclusion and hence of neglect (e.g., Scheper-Hughes, 1987). In the latter cases, families may try to invest their efforts in one child they think may have the best probability of success, leaving the others aside. In the case of unaccompanied Moroccan minors seeking to go to Spain, many families appear to make the opposite decision: they appear to neglect the child they think that will have more opportunities to succeed in migration. If a boy feels himself excluded from the family investments, this may in fact encourage him to go to Spain: to select himself into a pathway of migration. In such cases, the conditions the boy encounters in leaving may leave him in far greater situations of hardship than he endured at home.

In this paper, I see the category of neglect as the central concept in several complex social transactions. It is relative, in that it acquires meaning in a particular social context and also in that one situation of neglect may be worse than another Not only that, but neglect may be intentionally cultivated for strategic reasons, as in cases in which being neglected is a criterion for being allowed to stay. Finally, a child who appears to be neglected may in fact be the child on whom the highest family hopes rest. In the present case, the boy who is attempting to migrate alone may be the one chosen by his family to go because they see him as the best hope for them all to advance. In the future the migrant boy who is able to become what international observers would classify as "neglected" may be the one who will support the rest of his family. Independently from who decides to migrate or how they decide to do so, many neglected minors in Spain are the "promised children" in their families.

Whereas birth initiates the process of producing a family member, the fact that reproduction is a social process (Marx, 1967; Bourdieu and Passeron, 1990; Ginsburg and Rapp, 1991) means that biology simply marks the start of a child's social life trajectory (Bledsoe, 1990). In Morocco, children are geographically mobile for many reasons: schooling, trade apprenticeship, marriage, or simply by going to live with relatives who have access to "elite" culture. All are seen as strategies for socially reproducing a child who will be useful to a family. It is also, however, a potential case of social reproduction in jeopardy.

The pattern of sending Moroccan children away from their parents to live elsewhere for training or schooling, or simply to live with other family members, is nothing new. While migration close to home has long been a way of promoting children and transnational migration has in some ways simply become an extension of these former practices, North African children have been coming to Spain for decades. Thousands have come under family reunification programs, educational programs, and 
work. What is new, only within the 1990's, is the rise of those who migrate alone: "unaccompanied minors," as they have come to be called, without any relative or responsible adult. These children migrate to a different continent, far away from close family assistance.

Since the period of lone child migration began, it has become clear to the Spanish social services dealing with immigrants that Spanish laws governing immigration themselves have begun to affect both the types of children coming and how they come. Because pathways governing legal entry into Spain are closing so rapidly, individuals have a far greater chance of being allowed to stay if they are judged to be both children and neglected. Hence, the remaining opportunities for Moroccans to get a legal foothold in Spain are narrowing to children who have a chance, small as it may be, of both making the trip and, once they arrive, of fitting into the protection system as "neglected minors." As this possible avenue into Spain has become known in Morocco, even if the legal technicalities are vague to them, middle class as well as poor families have been defining new strategies for children migrating to Europe. Paradoxically, therefore, the possibility opened up precisely by the conventions that seek to protect children are having an unintended but quite predictable consequence: increasing instances of neglect.

Spain and Morocco may have signed human rights accords intending to promote and respect them. How these treaties apply internally is one matter. But for the ranks of the excluded, they can have the opposite effect. Tightening the laws on the free movement of people and making it difficult for them to legalize their situation forces prospective immigrants to shed images of "normality" so they can fit into a category of deviation - in this case, "neglect" -- regardless of the stigma it may entail.

The phenomenon of Moroccan children trying so hard to leave their families - to make themselves neglected in order to fit into a category of migration acceptability -- points to very wide problems of inequality and underdevelopment in the face of expanding global economies (e.g., Wolf, 1982) and their impact on North-South relations. On the one hand, the "inclusion" side of EU policy creates conditions of belonging that certain people can meet, usually those of wealth or of EU citizenship. The same efforts to include, however, also produce exclusion. Tightening their geographical and legal boundaries, EU countries seek to create ever-wider buffer zones between Europe and its peripheries. While making internal movements easier, as the creation of the Shengen space (signed by Spain in 1991) sought to do, with ideals of democracy, human rights, child protection, etc., and expanding its borders to the east, Europe has simultaneously been creating what has been called "fortress Europe," 
especially vis a vis the South. To avoid having to extend massing amounts of humanitarian aid to needy people, Europe tries to keep them from entering Shengen space. The fact that just 14 kilometers divide Morocco from Spain makes this case a special one to observe, both for the impact of the EU on Morocco, and for the efforts by Moroccan people to find ways to gain entry to the EU.

At present, the most rigid EU border creation mechanisms are arising in Africa, the sources of tens of thousands of migrants and many more would-be migrants. Morocco in particular is receiving EU money to control what Spain calls its "Frontera Sur" (southern frontier). The result has been the deaths of dozens of Africans in the fences dividing Morocco from the Spanish enclaves of Ceuta and Melilla. While recent efforts to stop immigrants from Morocco have had some success, the main result has been to alter the routes that immigrants target. EU-driven physical and administrative barriers expanding across Morocco have forced many would-be immigrants to try to come from Mauritania, Senegal, and The Gambia by ever-more distant and dangerous routes.

Confronting instances of what has come to be called "irregular" migration, authors such as Delgado (1998), De Genova (2005), and Calavita (2005) show that immigrant "illegality" is the product of policies of exclusion and increasingly restrictive immigration laws. In a similar manner, this paper will argue that global inequalities create the conditions that give rise to unaccompanied Moroccan children who arrive in Spain: Spain creates categories of marginality and deviance and fills them with people. As it will further show, however, this same possibility of being labeled deviant can be advantageous. This possibility opens up at the juncture of two sets of policies: childhood international humanitarian laws, for which the country's "Comunidades Autonomas" or regions have been given administrative responsibility, and the Spanish "foreigner law," under federal jurisdiction. In the case of unaccompanied children from Morocco, this disjuncture between Spanish policies - labeling Moroccan children as neglected children who need protection, on the one hand, and, on the other, as irregular immigrants - creates perverse motives on both sides: to create neglected Moroccan children, on the part of families, and, on the part of migration authorities, to imply that the families who produce these children are deviant.

With the rising restrictions on movement to partake of the resources available in Europe and opportunities for gaining amnesty in an "extraordinary regularization process" diminishing, a shrinking set of possibilities remains open. Among them is being an unaccompanied minor. After World War II the world was concerned about so many people left as refugees and especially about so many 
children who lost their families during the war. As a result, on December 10, 1948 the General Assembly of the United Nations adopted and proclaimed the Universal Declaration of Human Rights. Member states pledged themselves to promote universal respect for and observance of human rights and fundamental freedoms. The General Assembly proclaimed this Universal Declaration of Human Rights (1948) as a "common goal for all nations that they should strive to promote respect for these rights and freedoms and take measures to secure their recognition and observance, both among the member states and among the peoples of territories under their jurisdiction". Article 25 of the declaration gives especial attention to the child: "Motherhood and childhood are entitled to special care and assistance. All children, whether born in or out of wedlock, shall enjoy the same social protection."2

This paper will describe the social construction of "neglect" in the case of the unaccompanied minors coming from Morocco and analyze some of its effects, especially in creating neglect. Most notably, it will explain how some boys intentionally put themselves in situations of neglect to try to become wards of the State and to obtain a legal residence permit. This paper will highlight the perverse and paradox effects of this phenomenon, starting with the State's intention of protecting the children but ending with many children in situations of neglect. Focusing on the Autonomic Community of Catalonia in Spain which, along with Andalucia and Madrid, is where most unaccompanied Moroccan minors have come, I present some data on numbers, places of origin, motivations, and methods of migration of the children. To understand how becoming neglected has become an opportunity to gain legal status, I also describe the history of relations between Spain and Morocco and the emergence of different Spanish laws on immigration and on child protection. I finish by illustrating with some cases how some of these children end up in situations of neglect, and offer some preliminary conclusions.

\section{Background of the present study}

My previous work examined the lives of unaccompanied minors in Catalonia, Spain, where many Moroccan children come (Empez: 2003). This work was based on my experiences in my job as a social worker in Catalonia specializing in immigrant cases and in dealing with Spanish policies on the handling of unaccompanied children who migrate to Spain. I began participant observation in

2 http://www.un.org/Overview/rights.html 
Barcelona in 2001. My master thesis (Empez: 2003) on unaccompanied minors included four years of fieldwork, in Barcelona, including visits to Tangier, Morocco, with some of the families of children I met in Spain. My most recent fieldwork, in Morocco, was on family migration dynamics, funded by the Max Planck Institute for Demographic Research and forming part of my PhD dissertation for the Universitat Autonoma de Barcelona. During fieldwork in Tangier, from April to October 2006, I studied socialization practices and reproductive strategies among families who send child migrants to Spain, and the process of decision making in child migration. The findings then took me back to Catalonia, where I interviewed professionals in the minors' protection system dealing with unaccompanied minors.

During the fieldwork in Morocco, I relied most heavily on qualitative methods: participant observation, open-ended interviews, discussion groups, informal conversation, analyses of media, and so on. I had contact with many boys who were trying to cross to Spain from the port: those in the street, those from rural areas, those in temporary street situations, and the ones coming from the city of Tangier. My subjects included people from Tangier and rural people from the district of Beni Mellal; families of children (and children themselves) who were returned as "minors" in family reunification by Spain; adults who wanted to migrate; families with children in Spain; exunaccompanied minors who were repatriated from Spain as adults; families with adult members living in Europe; young workers; students; older women; people living or working in the port; school teachers; NGO (non-governmental organization) workers; and members of Moroccan authorities. The research included as well secondary analyses of survey data (CERED, ${ }^{3}$ the Spanish Municipal Register, the Spanish Census of $2001,{ }^{4}$ etc.).

\section{The numbers of unaccompanied minors}

The Spanish mass media often describes unaccompanied Moroccan children as if they were coming in massive numbers, overflowing the Spanish welfare system. It is difficult to know how many unaccompanied migrant children arrive because the official numbers are not clear, and not all of them end up in the protection system, where they are officially counted. Estimates from 2005 from

\footnotetext{
${ }^{3}$ Centre d'Edtudes et de Recherces Demographiques; http://www.cered.hcp.ma/
}

${ }^{4}$ http://www.ine.es/ 
ConRed $^{5}$ show 30,000 unaccompanied minors throughout 17 countries of Europe: an estimated 1000 to 2000 new minors per year in Spain, with an average age of 14-15 years. The real numbers, however, are probably much smaller, at least in Spain. The Catalan Child Welfare System does not have clear data. Sometimes the numbers are reported at different points in time, and data from different offices in the same system can be different. In some cases, confusion has arisen because of the mobility of the children from one Autonomic Community to another. Sometimes they even come from other European countries. Many give different names in different places. The result is that some Moroccan children are counted more than once while others are invisible in the numbers because they are in the streets or are in fostering or domestic service situations with Moroccan families, and are not reported.

Having stated the limitations, I nonetheless show the numbers for Catalonia from the Direcció General d'atenció a la infància i l'adolescència ${ }^{6}$ (DGAIA), published by Capdevila (2003), for the years 1998 through 2001. Data from 2002 and 2003 were unavailable (See Figure 1). For 2004 and 2005 I use Institut Català de l'acolliment i de l'adopció of the Direcció General d'atenció a la infància i l'adolescència $(2005,2006)$. I use these data, because they come from official sources, but I should add that the administrations had given different official numbers for the same year, and in fact are disputed by some NGO's and the Sindic de Grenges (Catalan Persons Defender). ${ }^{7}$

Figure 1

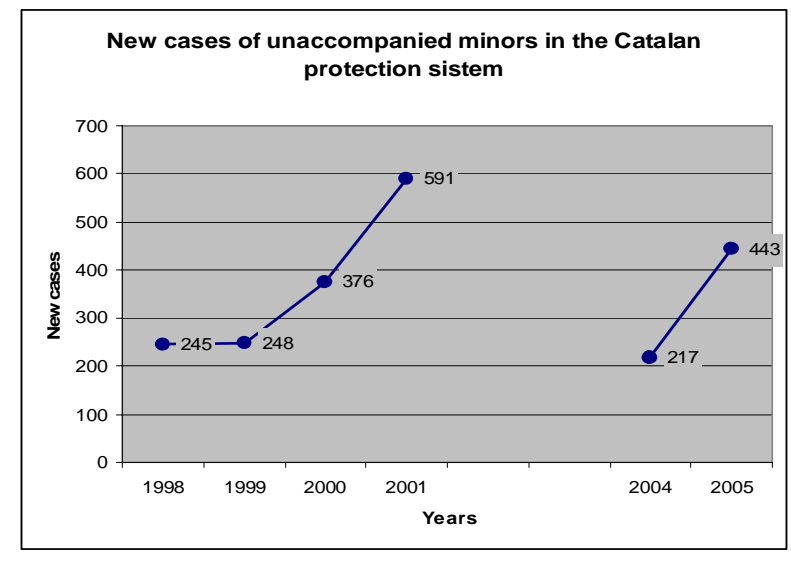

As Figure 1 shows, the numbers of unaccompanied minors were stable for the years 1998 and 1999.

\footnotetext{
${ }^{5}$ CONRED: a virtual community aimed at preventing violence against immigrant children and adolescents who have no social support network. See http://www.peretarres.org/daphneconred/estudi/index.html)

${ }^{6}$ Catalan Government General Direction to child protection system.

7 http://www.sindic.cat/ficheros/informes/37_Situaciomenorsimmigrats.pdf
} 
The large increases in 2000 and 2001 could be related to the creation of the first emergency resources to attend these minors, and the better knowledge in Morocco about the minors' welfare system and the opportunities to gain legal status. The apparent drop of new cases from 2001 to 2004 may stem from the Catalan welfare system's announcements of its intentions to reunify unaccompanied children with their families back home, prompting some of the boys to leave and try their luck in another Autonomic Community such as Basque Country.

\section{History of migration between Morocco and Spain}

The migration of unaccompanied children from Morocco to Spain represents a statistical anomaly - a relatively small number - though there would be many more such children if all who wanted to come were allowed to do so. It is also a number that is decreasing, with intensified efforts by Europe to stop the pattern. To set a context for the rise of the unaccompanied Moroccan minor phenomenon, this section reviews the historical relations between Spain and Morocco, looking especially at laws that have affected the migration of unaccompanied minors from Morocco to Spain.

Morocco and Spain have had a longstanding history of ambivalent relations. One of the most significant events in history occurred during the period of Al-Andalus (VIIIth through XVth centuries), when Arabic Muslims who had co-existed with Spanish Christians in Spanish territory eventually were defeated by the Christians and forced to leave Spain. In 1912 Spain claimed several places in Morocco that it designated as "Spanish protectorate" (in Arabic, Islam yat Isb niy bi-l-Magrib): some in the north of the country and some areas in the Sahara desert. The Spanish protectorate lasted until 1956 but there still exist echoes of these times in Northern Morocco: the use of Spanish words mixed with Arabic; Spanish-style buildings like theaters, houses or factories; etc. In the Spanish civil war Moroccans played an important role, supporting the dictator Francisco Franco; what became known as "La guardia mora" (1936-1939) promoted fear and negative stereotypes of Moroccans, many of which still exist.

Migration between Morocco and Spain has been a pivotal part of this shared history. What has changed have been the characteristics of that migration. Before 1985, a visa was not required to enter

\footnotetext{
${ }^{8}$ Moroccan Guard.
} 
to Spain; there were temporary agricultural and industrial workers coming to Spain for temporary work, without the intention of staying long in Spain. Such migrants were largely young men. Other Moroccans came for education or as tourists. Despite the difficulties they encountered, Moroccans found it relatively easy to come and go from Spain.

In 1985, Spain created the first foreigners law (La Ley de Extranjeria). ${ }^{\mathbf{2}}$ This highly restrictive law, coinciding with, and as a requirement for, the entry of Spain in the EU, was created mainly for police control over migration, punishing people in irregular administrative situations. Not reflected in this law was the question of permanent residence permits for temporary migrants. The second foreigners law, created in 2000 (Law 4/2000), was intended, nominally, to integrate migrants, and hence differed in many ways from the previous law. It facilitated family reunification and the acquisition of a permanent residence permit, and it created forms of regularization for irregular migrants. However, the government decided that these measures were creating a "calling effect": making it easy to stay would encourage other would-be immigrants to try to come. Soon thereafter, the government initiated a reform of the law $4 / 2000$ that became effective in the law $8 / 2000$. This law curtailed considerably the political, employment and social rights of irregular immigrants, and made irregular migration an infraction punishable by expulsion. This law also tightened family reunification requirements, making it more difficult for migrant families to obtain a permanent permit.

Presently we have the law (Ley Organica) 14/2003, and its legal coding "Real decreto 2393/2004", which is even more restrictive than the previous ones. Under this law, migrants can lose their residence if the conditions under which they obtained their permit change within the first five years, or until they get an individual permanent residence permit. For example, if a woman who came with her husband as part of family reunification is divorced after three years, she will lose her residence, because the reason for which she was able to obtain the permit is no longer in effect. Another example is that if someone with temporary residence and work permits loses his job, he can lose his papers, making him vulnerable to exploitive work conditions to try to keep the permit. Another notable legal change was that which appeared in the law 4/2000. Previously if a person stayed for five continuous years in Spanish territory in an irregular administrative situation, he could apply for a residence permit for extraordinary circumstances. Now, irregular migrants can get a permanent residence permit by marrying a Spanish national. Another way of regularizing one's status is through what Spanish law

${ }^{9}$ Ley Orgánica 7/1985, de 1 de Julio, sobre derechos y libertades de los extranjeros en España) 
calls "arraigo" meaning "root." This consists of proof of having stayed in the county for three continuous years, having no police record, having a job contract lasting at least one year, and being closely related to a legal resident (parent, child, or spouse; not qualifying are siblings, cousins, or other relatives) -- or by possessing a report expedited by the social workers of the local City Hall concluding positively that the migrant had developed social and cultural "roots" in the country. In short, it has become extremely difficult to gain legal status if one enters in an irregular way.

The current foreigners law (RD 2393/2004) contains several other provisions for legal entry and stay in the country. Among them are family reunification, a student visa, or a job contract obtained in the country of origin. Most Moroccans in Spain, however, are not in a situation that would allow them to apply for any of these permits. Concerning work, for example, Spain has what it calls a "contingente" an allocation for a specified number of foreign workers who can come to Spain to work in specific jobs which the Spanish employment market cannot cover. ${ }^{\mathbf{1 0}}$ This contingent changes every year, and only certain companies are allowed to requisition workers. The contingent can be nominal or general. In the case of General Contingent, just some companies can apply for it. Most of this labor is designated for agriculture, construction and "third sector;" that is, services. Participating companies can apply for workers, but they cannot, in theory, choose special persons; the selection is made in the origin countries, sometimes by private selection companies, sometimes by the local Spanish consulates or embassies. In the case of the Nominal Contingent, the employer can apply for one specific person, but just in jobs not covered by the general contingent or applied for by any Spanish or foreigner with a working permit in Spain. Even with these allowances, the system has been inefficient and inequitable, forcing individuals to rely on established economic and patronage networks.

\section{A window of legal opportunity: "neglected" children}

In Morocco, the boys who come unaccompanied to Spain not only form part of a family - a corporate group; they may in fact have been delegated by the family to migrate. Whether the family or the boy makes the ultimate migration decision, the intent is to help the family. What is important about these children's moves is the potential impact on future vital events of families, who are anticipating the problems and needs of all their members. Since a successful migration may affect not just the

10 Articles 77 to 80 of the current foreigners law (Real Decreto 2393/2004). 
individual boys' vital events but also is intended to affect the vital events of other family members, Moroccan families try to fit their young members into whatever social categories will best qualify them for legal status in Spain. The category of "neglected" is the most obvious choice. This is so first because these boys are going by themselves; second, and even more important, families know that if the Spanish authorities recognize the children as neglected minors, this status can give them legal standing as wards of the state. Because of Spain's legal rules on immigration and because of its commitment to looking after unaccompanied children, Moroccan families see children as the members who have best opportunity to succeed in such a move and hence as most likely to bring benefit to the family, even at the cost of taking risks or of becoming seen as "deviant." Only by being declared legally a neglected minor, that is, can the boy obtain the residence permit. And only through the Spanish state's declaration of him as neglected by his family can a boy who is chosen to go keep good relations with the family.

As the discussion above has implied, Spanish laws governing foreigners are making it increasingly difficult to come to Spain legally for any migrants from poorer countries, or to gain legal status once they arrive. Where, then, are there any opportunity at all for obtaining legality? For many families, a small window of legal and temporal opportunity has opened up in the international conventions governing the protection of unaccompanied foreign children.

In November 1989, forty one years after the Convention on the Rights of the Child ${ }^{11}$ was signed, the Convention was adopted by a resolution at the forty-fourth session of the General Assembly of the United Nations (1989). Under this agreement, children were declared to have special needs for assistance and hence to be entitled to special protection. All signatory countries (all have signed except the U.S. and Somalia) were obliged to take care of unaccompanied or neglected children, regardless of nationality, race, color, sex, language, or religion, within their jurisdiction. The UN recognized that each country had its own internal laws and policy structures, so every country should create its own arrangements for how this protection was to be enacted. For example, in Denmark, Belgium, Portugal and Sweden (CONRED 2005), ${ }^{12}$ unaccompanied children are treated as asylum seekers, irrespective of age, while Spain and Italy chose to treat them as neglected minors, effectively putting them in an ambiguous position between the foreigners law and the child protection system of

$11 \mathrm{http}: / /$ www.unhchr.ch/html/menu3/b/k2crc.htm

12 http://www.peretarres.org/daphneconred/estudi/index.html 
the Autonomous Communities. ${ }^{\mathbf{3}}$

Spain has made the local autonomous communities responsible for overseeing its international responsibilities regarding children, meaning that the protection system for children, citizens and foreigners alike, belongs to the different Autonomic Communities. In the Catalan case, different laws apply to the protection of childhood, but the most significant center on neglect. The following is the definition used by the Catalan childhood protection system in order to determine which children are neglected and which, consequently, should be the subjects of its protection:

\section{"We can consider minors neglected when:}

a) They lack persons who by law would take on the guardian role or when such persons are unable to take on this function or they would do so in a way that would put the minor at risk.

b) When there is any evidence of failure to carry out the protective duties decreed for the protection of these minors or [such guardians] lack the basic elements for the normal development of the minor's personality.

c) When the minor displays signs of physical or psychic mistreatment, or sexual abuse, or other similar things." (Law 37/1991 of 30 December on protection measures for neglected minors and adoption.) ${ }^{\mathbf{1 4}}$

Unaccompanied minors meet minimum condition "a" in that they lack guardians. Further, even those who have the state as their guardian are often at risk. Under the Catalan child protection system, minors with no guardian in the country should be automatically declared neglected and the Catalan government should automatically assume the role of "tutela" or custodian who takes legal responsibility for them. The complication is that the rules governing unaccompanied children from Morocco fall under both the childhood protection system and the foreigner's law. Under the foreigner's law, which would see them as adults, even when they are under the guardianship of the state and have food and shelter for a certain period, they still have an irregular administrative situation; meaning that they can still be sent back and they cannot engage in activities that require legal residence. Being in custody of the state is a way to gain legal status, but it cannot be obtained immediately. When a boy comes into the Spanish protection system, his case comes under a specific article, no. 92, about unaccompanied minors. Point 5 of that article of the foreigner's law says: "Passing nine months since the minor was put in the competent services of the minors protection, in agreement with section 2, and once having tried repatriation with his or her

${ }^{13}$ In the case of Catalonia, see Llei 8/1995, 27 de juliol, d'atenció i protecció dels infants i adolescents: the law of protection pertaining to teenagers and children.

${ }^{14} \mathrm{http}: / /$ www.gencat.net/benestar/dgaia/conceptes.htm 
family or to the country of origin, and this haring not been possible, will grant him or her the residence authorization to which refers the statutory law 4/2000, of 11 of January". 15 Thus, if a boy arrives in Spain and is judged to be both a minor (with legal papers or through a radiography test) and neglected, he should be taken to an emergency center created for unaccompanied children, and the government is obligated to try to reunify him with his family within nine months. After that period, if the government has not succeeded in reunifying him with his family or if the government determines that family reunification would not be in his best interest, he must be given a residence permit in Spain. The government has the obligation to protect the minor while it decides on his future: if he should be sent back to Morocco or if he should remain and be given legal residence. During that period, he should be kept in a center supervised by the childhood protection system.

In the case of Catalonia, as in almost all the other Autonomic Communities, the government, following the international laws of child protection for unaccompanied minors, has created specific resources for this category of children. However, it treats children from outside differently from how it treats those with legal status in Catalonia. In particular, separating them by origin, they create special centers for Moroccans, whereas the members of other communities, for example South Americans, are mixed with Catalan children. This creation of a parallel system of attention has been criticized by several NGO's (CONRED 2005, Save the children 2004, etc.). Under this parallel system, children from specific foreign countries can obtain protection if they can prove that they have nobody at all to look after them. (Catalan children or children who are members of other communities typically enter into the protection system by different circuits.) These children who can prove that they are totally unaccompanied must still wait nine months to know if they are allowed to stay, sometimes making their integration more difficult.

If, on the other hand, a child is found to have some relation in Spain, even a distant relative, he cannot enter the protection system. In most cases, however, relatives of that kind are not in the position to take care of the child, or have no interest in doing so, leaving him in a liminal situation: he does not fit into the category of unaccompanied foreign minor, and cannot enter the "normal" protection system. Forgotten by the system, he does not exist.

15 Articulo 92.5. Transcurridos nueve meses desde que el menor haya sido puesto a disposición de los servicios competentes de protección de menores, de acuerdo con el apartado 2 , y una vez intentada la repatriación con su familia o al país de origen, si esta no hubiera sido posible, se procederá a otorgarle la autorización de residencia a la que se refiere la Ley Orgánica 4/2000, de 11 de enero. (...) 


\section{The social context of child migration in Morocco}

In Spain, the children who have made these trips appear to be neglected. But few are neglected in their families before the migration attempts begin. To understand this paradox, we need to examine the context from which these boys are sent.

Many factors push these boys to migrate, whether directly or indirectly. Everything in Moroccan popular culture publicizes migration to Spain: TV, newspapers, Moroccans living in Europe who come in summer to show off their success, peers, etc. Nonetheless, families are the primary forces. Families want the best for their sons, but they also see a boy's successful migration as a way to guarantee security or help in their collective future. Boys who do not make it to Spain or who are sent back by immigration authorities are commonly met with disdain by their families who cast them as failures and refuse to accept them back as full members. Unless a boy has managed to reach Europe, and preferably also got papers, even when getting to Spain only to be sent back again, he is not seen as being serious about crossing, as wasting his time in the streets, and as not supporting his family.

Data from CERED in 2004 show that Morocco's population has nearly tripled in the last four decades. In 1960 Morocco had a total population of 11,635,000. In 2003 it was 29,520.000. Morocco has a young population. In 2003 the age group between 0 and 14 represented $30 \%$ of the total. If we relate these data to the high rates of unemployment and high school dropout and also the history of internal migration, we can get a better grasp of the meaning of the large number of boys and young men without a secure future who seek to come to Spain.

Most of the unaccompanied Moroccan minors in Spain come from Tangier and its surrounding region. Tangier is the capital of its province. It has a population of about 500,000, and the province formed by Tanger-Tetouan-Larache has a population of 2.3 million. Tangier is the principal Moroccan cosmopolitan city, and it contains an extremely varied mix of people. During the period of 1945 to 1956 it was an international enclave, populated by Muslims, Christians and Jews. 
In the last 30 years, Morocco has experienced enormous migration movements from the rural areas to the cities. In many cases, families came from rural areas further south to urban areas in the north driven away by the droughts in the 1980's. This exodus is still ongoing. In rural areas there remains much illiteracy and high unemployment; rural jobs are limited and badly paid. Like other cities, Tangier has received most migrants from internal rural to urban migration. It is also absorbing people coming from other parts of Morocco or even other countries of Sub-Saharan Africa who want to migrate to Europe. The distance to Europe -- Algeciras-Tangier -- is just 14 kilometers, and the city is well known for its industry in smuggling people and goods. It is also a place from which the "irregular migration boats" (pateras) leave. There used to be a considerable illicit migration from Tangier, but after the implementation of Spain's “Sistema Integral de Vigilancia del Estrecho" (SIVE) ${ }^{\mathbf{1 6}}$ in 2002, just a few boats now leave from this area, and people are being forced to take more risky routes such as via Mauritania and now even The Gambia (Pérez; 2005).

The accounts of authors such as Jimenez (2003) and Konrad (2005) give us an idea of the migratory context: Twenty-five percent of Tangier's families do not have electricity at home, and the city is still growing, expanding particularly in the suburbs. There is a significant difference between the peripheral areas, with houses of the poor, and the coastal area, with its modern apartments and big houses. The population of the towns around Tangier migrates to the city, but the suburbs receive most immigrants, so Tangier grows outward, creating ever-greater inequalities among the different neighborhoods, some of the houses being of quite unstable construction, and lacking good transportation and communication with the center of Tangier.

In Morocco anyone who is trying to migrate in an irregular way calls himself "harraq." Coming from the classical Arabic word, harq, this means "to burn," as in "to burn ties." It does not literally mean this, however. It has become the expression that describes the people who are attempting to migrate in an irregular way. Not all the "harrag" try to migrate from the port area, but the term "harraq," when used to describe children, implies that these children are in the street as a temporary position in time and space. They are seen as in a temporary street situation -- as having a purpose or "calling" -- and from whom much good might come in the future. Possibly hoping to capitalize in the future on the success of some of the children who succeed in reaching and staying in Spain, even the Moroccan port police, who are supposed to take these boys into custody or evict them from the port, often turn a

16 Integral Vigilance of the Straits System 
blind eye to their presence. No one identifies a boy who is serious about his migration as a "street child", in the sense of leading an undisciplined, idle life of petty crime. His goal is not to live in the street but to leave the country. For those boys who have not yet succeeded, however, life in the street may be necessary to survive.

Many boys trying to leave Morocco live in the port area of Tangier. My first trip to Tangier was in 2001, when my interest in this research began. My first impression upon arriving was the perception of the border and all the organization (formal, non-formal and informal) around it. Even back then, the port was a graphic representation of the rest of society. In it was an enormous variety of people all interacting in the same space: fishermen, tourists; port workers, police, street children, truck drivers, harraqs. All occupied the same space but for different purposes. Often one group was invisible to the others.

For would-be child migrants conditions of life in the port are extremely hard. They form informal support groups of individuals, and they divide the port into different areas inhabited by groups of boys from the same neighborhoods or towns. They also need certain skills to survive: knowing how to obtain water and food, how to find a safe place to sleep and, most important, how to integrate themselves with a group of other would-be migrants so they can gain group protection. They are not allowed to enter the port, so they have difficulties getting in and out of the place. They must contest not just security police but one another for the occupation of spaces to live and from which to try to migrate: especially for a place under a truck. They are exposed to the weather; they must avoid the police and security services; and every day they must struggle to obtain food and shelter, and to try to get into a ferry to reach Europe. Many of these boys suffer abuse from adults or other boys, including sexual abuse. They also suffer from maladies associated with their living conditions: skin diseases, malnutrition, high fevers, and sunburn. They also suffer from accidents, being beaten by the police and security guards, getting bitten by guard dogs, getting fractures from falling from the walls around the port, drowning, getting run over by vehicles, or getting hit by boat motors. According to my records from discussions with the children and port workers, fourteen deaths occurred from such causes during my fieldwork in Tangier Port between May and October of 2006. None were reported in the local press. Since March 2006, there has been a bus that deports rural children suspected of trying to migrate irregularly from Tangier and deposit them in the rural areas, sometimes irrespective of where their families live. Although those who are sent away usually return the next day, this is a way of discouraging them from their migratory intentions. Despite these conditions, some of these boys 
refer to the effort to migrate as a job where you must check in every day. Most of these boys keep intermittent relations with their families; some even undertake short visits between migration attempts, though they almost inevitably come back to the port to avoid the shame of having failed to reach Spain - and because this is their job.

\section{Unaccompanied Moroccan children coming to Spain}

It is difficult to categorize unaccompanied minors; each is a particular case. But we can distinguish some differences according to their mode of entry into Spain, who made the decision for them to go, and their current situation. Most basic is their legal status: as "regular" or "irregular" migrants. I describe first the most common channels of regular migration, and the ways in which the majority of minors enter Spain.

Moroccan children come legally to Spain in several ways, based on special provisions in the Spanish law for minors. Many come with student visas. Others come as part of normal family reunification packages, to join one or both parents. There are also ways of coming based on fostering; such children come with a tourist visa, aiming to stay in the country after the visa expires, under the guardianship of a relative. In some cases the child comes himself and ends up in a fostering situation, by agreement with the family or because he had difficulties getting into the protection system. In another version of fostering, a family in Morocco may ask someone now living in Spain, usually a family relative, to take a child. Children who come in such ways are often considerably younger than 16 - some as young as 10 or 11. The rationale for sending them this young is that they can mingle with Spanish society far more readily than can older children who come for the first time. Children who come under age 16 are allowed to attend school, where they can learn Spanish and Catalan. In addition, they face less surveillance by the state than do older teens; and they are considered by fostering families to be easier to care for and discipline. In some cases, however, the "family" relation is quite distant, and the arrangement can be exploitive, especially for girls, who are expected to stay close to home. Most girls in particular do not even come through the protection system at all, migrating as fostered children or domestic servants or, in the worst cases, as prostitutes. Only for children who are "adopted" does Spanish law give residence rights. To qualify as an adopted child, however, a child must have a judge's order decreeing the parents unfit. He must also have capable guardians in good residence and employment standing in Spain who agree to take over. As well, the 
child needs proof of continuous residence in Spain for a period of two years, as demonstrated by registration with the "padron," the local city hall registration. Adoption is all the more difficult to enact because Islamic societies forbid adoption; hence, presenting evidence of custody that would be commensurate with Spanish legal categories is often impossible. Consequently, although most children who families try to claim as adopted enter in a regular way, such as through a tourist visa, they will become "irregulars" after the visa expires, unable to legalize their status.

The other legal state in which Moroccan children come to Spain is as "irregular" immigrants. Of those irregular child migrants who try to come by themselves, boys predominate, and they tend to be around age 16, when they know they are eligible to be wards of the Spanish state. Many attempt the journey by large transport vehicle, hidden under a bus or track that is being loaded in the port in preparation to make the crossing by ferry to Algeciras. This form of migration has little direct economic cost to the children or their families, but it is very dangerous. Most of these boys have made an individual decision, albeit with strong pressure from families, friends, and the media. The final category of irregular child migration is that of boys, usually from rural areas, who attempt the journey by patera boat. Such a journey can cost several thousand euros. Because it is the most expensive route that unaccompanied children can take, families are behind nearly all such efforts.

\section{Becoming neglected}

Below I summarize several ways in which neglect among Moroccan children arises, both migrants and those who are not successful in migrating, whether directly or indirectly. To illustrate, I use case studies obtained during my fieldwork and in some of my interviews.

1. Exposure in the port in Tangier: Many boys staying in the port in Tangier while awaiting an opportunity to cross are exposed to physical danger: a period of time that could last for years.

I met $\mathrm{H}$ in 2001. His family lives in the suburbs of Tangier, in a poor neighborhood, in a little selfconstruction house. His father is retired and the mother is a housekeeper; he has an older brother and a young sister. The summer of 2006, H was 17 years old, his older brother of 20 worked in a small leather factory, without contract and social security, providing the only income that enters the home. The small sister is still studying. He has been trying to cross for five years. He reached Spain three 
times but each time he was sent back. He sleeps during the day, and goes to the port at night. He had been beaten by the police and the port security members on several occasions. He argues that his family knows his intention, and they don't try to stop him, but they don't support him either.

They said [referring to his family] that I'm a "Shem kare"17 [drug user]. Though I just use drug sometimes, they don't believe me. One day I will reach Spain, then they will change their opinion about me. I will help them to get out of the poverty.

For $\mathrm{H}$, the family does not trust him or his real intentions to try to reach Spain. Sometimes he spends some nights at the port and uses the house just as a base camp to rest and recover.

For $\mathrm{H}$, the fact of being the second child is crucial; his older brother cannot think of migration because he had to work to support the family. $\mathrm{H}$ is free of this duty, but the family could not afford to pay his school fees, and since the small sister showed more interest in school and better aptitude than he, she was the one they supported to study. H had many friends from the neighborhood who are now in Spain. They told him about the protection system. He still lives with the family who gives him food and shelter. His family does not think he is serious about trying to cross; they think that he is just having fun with his friends and taking drugs. $\mathrm{H}$ is risking his life daily in the port; his only activity is to try to migrate, so he left the studies and other activities that others of his age could pursue. His family feeds and gives shelter to him but they do not exert functions of protection nor of communication with him.

The case of $\mathrm{H}$ represents the majority of the migrant boys who live in Tangier city, a boy who was able to draw on the occasional help of his family because they lived in Tangier. As I said above, however, the situation of the boys of the rural area is worse, because they lack support from their families while they are in Tangier, away from home.

$\mathrm{B}$ is another boy who has suffered from exposure and the harsh conditions of trying to live in the port and to migrate from it. Unlike the situation of $\mathrm{H}$, however, his family does not live in Tangier but in a distant rural area. I met B in the surroundings of the port area in May 2006. An illiterate, thin and shy rural boy of 16 years, he has been trying to migrate intermittently for two years. He spend some time

${ }_{17}$ Nick name for drug abusing boy who inhalates dissolvents. In Arabic "Shem" means to inhale and "kare" is the dissolvent. 
in his home in the rural area and some time in the Tangier port area trying to cross. So far he has never reached Spain. In June 2006 he broke his elbow when he fell from the top of the 6-meter-high wall that divides the beach from the port. He tried to live in the port in this condition, but the other boys made fun of his lack of luck. He decided to go back to his parents house (10 hours by bus to the rural area) until he recovered. Before he left Tangier, B told me that when he recovered he would try again. His family knows what he is doing, and makes comparisons to other boys who have obtained this goal. I asked him if he thought his family knows the conditions he lives in; he answered that boys never explain the real conditions of living in the port to their families because they do not want to worry them, but he thinks they can imagine how that could be. B thus represented a case of a boy experiencing neglect in the port, but because he was far from his family's support, he was forced not just to try to migrate but to survive, looking for shelter, food, a place to wash himself, etc. Like the other boys in such circumstances, he easily gets exhausted without any external support; as well, his clothes get older and dirtier faster than those of the boys from Tangier, and it is easy to recognize him by his ragged looks. This has made him more vulnerable.

2. Becoming a street child in Spain: A boy who migrates and becomes aware that he is going to be sent back to Morocco is very likely to escape the protection system and go to live in the streets. There, he feels that he failed his family members, and ends up without protection, either from the state or his own family.

One of the first motivations of this research started with the question of why some of these children ended up in the street (Empez 2005). Five years of intermittent field work in Barcelona, including talking with many of these boys and interviewing some of the professionals who interact with them, have persuaded me that a large number of boys mistrust the protection system, they are afraid to be send back to Morocco, and they are living without protection. As a social educator told me in an interview:

I know a lot of cases in which they [officials] gave them [Moroccan boys] a proposal to return based on the concept of family reunification. That means that they are not accepted to stay in Spain. If they stay in the protection system the police will come to take them and they will be sent back under family reunification. These children don't want to return and they end up in the street or leaving for another autonomic community. Sometimes this other community gives them a different response, or it helps them to integrate, but what happens is that they 
(the minors) develop a certain mistrust of the protection system. And kids who stay here in the streets in Barcelona and they don't want to return, what do they have? If they don't leave the center, they will be repatriated; then they are minors starting moving around to other parts of Spain or even Europe, searching for a place that really welcomes them, or they will make a way of living from the street.

Some boys, if they have some friend or relative, can live apart from the system like some irregular adult migrants, but most of them end living in "Harbas", occupied houses in poor conditions, and making the street their way of life. A large number of these boys end up in the justice system or in mental care. The same social educator pointed out:

But of course this makes them exhausted [desgatats], insecure and mistrustful. At the end they become a fulfilled prophecy.... We can find some small kids who when they first arrived they were 13, they were in Madrid, then came here; after from here they were sent back and I don't know. The kids have been switching communities, because everywhere gives them the same answer and they don't really want to leave. And then of course they are kids that since the 13 to 16 or 17 were in the street, or entering and living the centers, they are really, really, deteriorated.

Especially when they know that they are going to be sent back in family reunification, most try their luck in other Autonomic Communities; if unsuccessful, they move into the streets. These boys depend on their social networks and their personal abilities. Many become excluded, consuming alcohol and drugs. It is also common to observe self-injury cuts. If they escape the protection centers, no one goes to look for them.

As examples, I knew three boys in April 2006 who left the child protection system because they were aware that they were going to be sent back in family reunification, and lived for two months in the streets. After a time they decided to leave for Basque country, where they spent three months. The new autonomic community has not yet decided about the future of these boys; two of them decided to stay but a third one, tired and scared, decided to go back to the previous autonomic community, where he lived in the streets. He was caught thieving in November 2006 and now is in a justice center. 
3. The risks of family reunification: A boy who manages to get to Spain may be sent back in socalled "family reunification." For children who arrive in the Spanish protection system, they know they are unwelcome and unsafe, but the possibility of being sent back to Morocco to their families is hardly a goal. Rather, it is a threat that hangs over them.

Failing in his plans and those of the family that invested in him, he will try again to migrate, eventually worsening the relation with his family. It is not the aim of this paper to focus on family reunification, but my observations in the field and in interviews with "reunified boys" and professionals persuaded me that all the so-called family reunifications that are been made do not fulfill the requirements under the law of family reunification that was made to guarantee the right of living with the family (see also Jimenez, 2003, 2004, 2006). As the main organ of child protection, it becomes a pathway to neglect because these boys will not be welcomed back in their families, who do not understand the reason why their child has been sent back, and will blame the boy. If other boys have made it, they reason, he must have done something wrong.

As an example, I met A in the Tangier port area at the end of April, 2006. He was 17 years old, and had just returned from his rural area to Tangier port to try to migrate again. He seemed to me a very shy boy. After seeing each other many times we developed a good relationship and he became one of my best informants and friends. I also visited his family in the rural area, which helped me to understand this entire phenomenon.

When he was 15 A managed to get to Spain. He lived first in Almeria, working in the fields. Then a compatriot told him that as a minor he could have benefits of the protection system so he moved to Madrid and was accepted in the childhood protection system where he lived 14 months. According to the Spanish foreigners law, he should have been given a residence permit after nine months in the protection system. Instead, he was sent back in family reunification in March 2006. His repatriation was well known in the national newspapers for its spectacular execution. The police came to look for him at two o'clock in the morning. When he realized what was happening, he entrenched himself in his room, barricading it with furniture. The police tried to get in for more than four hours; he threatened to kill himself if they came. When the police finally broke down the door he was trying to escape with sheets from the window off the ninth floor. Another police officer, knowing what could happen, was on the eighth floor and rescued him from falling. In a state of shock, he was transferred 
to the airport, where a doctor saw him and put him on the plane. They brought him to Casablanca, where he saw a judge and was told to go home. His family, however, knew nothing of this "family reunification" until they saw him arriving. The family and the entire neighborhood could not understand why he was sent back. Ashamed, he spent just a week with his family in the rural area, and then went back to Tangier to try to migrate again. Ever since, he has been living in the street situation in the port. He had been beaten by port guards three times. In summer, with the annual arrival of the Moroccans living in Europe, an event in which the returnees display their wealth and look for brides -and the city puts on an extravagant welcome -- his father told him: "The only thing you brought from Spain was your long hair." A knows that is not easy to go back to Spain, but he argues: "there is no alternative." When I visited his family, he just agreed to go with me because of my request that we do so, and he returned to the port as quickly as possible. The situation with the father was tense; they love each other, but all the hopes they had in his migration were gone. In their expectations, he was supposed to be the first to go and then help his old brother to migrate too; then his father of forty five could retire. Now they do not to trust each other; both blame each other for A's current situation.

As this case suggests, the situation of the boys being sent back is worse than the ones who never reached Spain. They are victims on the one hand of the policies of family reunification, seeing their migratory hopes dashed after reaching Spain, and on the other hand receiving humiliation back in their own country, becoming a target for laughter of neighbors and relatives. They had the dream of Europe in their hands and they let it escape. The majority return to try to migrate again, often in worse conditions that they did the first time. Now they are older, they mistrust the protection system and they are morally lowered. Others become socially excluded, with problems of mental illness or drugs abuse. Because family reunification under such conditions is involuntary, few are welcomed back by their families.

$\mathrm{H}$, another boy I first met in Tangier, was sent back from Spain after eleven months in the protection system under family reunification. When he arrived, his alcoholic father beat him, arguing that it was his fault to be sent back. He tried to go again in June 2006 and reached Spain. He lived in the streets for several months until he met a lawyer with an NGO who explained his situation to a judge. In October 2006, the judge decided that the repatriation had taken place without warrants. Pointing out that the boy was sent back after the nine months, the judge declared that the boy had to be returned to the Spanish protection system, after being unattended all of this time. The history of $\mathrm{H}$ was traumatic, but he was lucky to find the help of an NGO. Most boys in his situation, however, who are returned 
to Spain, stay away from the protection system living in the street, and fall into marginality and social exclusion.

\section{The consequences of "success" in the childhood protection system: What families and} their sons both want has the perverse effect, given the severely limited economic and migration options available, of forcing these boys to become neglected: to assume adult roles at very young ages, to take care of themselves, and live apart from their families. Achieving success in Spain requires that they be neglected physically, in that they are not with the family and also that they are put at real risk of neglect and mistreatment in the Spanish child protection system.

I first met F, then aged 17, in Barcelona in 2002. He had come to Spain one year earlier. He later obtained his residence and work permits and got a good job in a factory. Talking with him, I learned that he badly misses Morocco and would like to go back to live with his parents, but he has a responsibility to help his family and they would not understand if he decided to go back. Like an adult, F. feels the difficulties and struggles of migration, but he is a young boy. Some can handle the situation, but others who, even after succeeding in getting to Spain and becoming legal, experience anxiety, depression, and other mental problems related to this lonely migration.

I met J's father in Morocco in the taxi he was driving at the end of April 2006. He asked me if I could find his son, who left two months ago as an unaccompanied minor. He knew the son was in Barcelona. Keeping contact with the father, I started to ask about the boy in my Catalan protection system and informal network. The father told me that he could not sleep thinking about the situation of his son. After a month I found one educator who knew him. When I brought the news to the family, they were really happy. Their situation was not of extreme poverty, but they thought that the migration of their son would give them a possibility of upward mobility. Knowing that only a "neglected" child would be allowed to stay in Spain, they exaggerated their current situation as being one of poverty, and as one of problems between the mother and the father, when a social worker from Catalonia called them, to ensure that their son would be accepted in the protection system. Right now, there is no way to know the real situation of the families. Spanish officials must do a telephone interview. In most cases families with more skills know what to say to get their child accepted in the welfare system in Europe. Families without resources, by contrast, do not know how to act, making it more likely that these children will actually be sent back to situations of neglect. 
Most boys who manage to stay in Spain because of their "neglected" state are proud of their accomplishments in managing to stay, but they stress that they lead a hard life. Many of them report that they feel lonely and especially at times of festivity like Ramadan or Aid al Kabir, which are major holidays in their countries of origin, both being festivities involving families. At such times, they must pass the time alone in Europe. They say they cannot reveal the struggles they undergo in Spain because they do not want to worry their relatives. Sometimes they feel pressure to send money, when they do not even earn enough to live themselves. They can only go to visit their families if they have enough money, often through borrowing, to pretend that they have an easy life in Spain.

\section{Accompanied but unattended: The rise in what I call "transcontinental fostering", in which} children move in with relatives or family friends, means that these children have shelter, protection and food; some of them, if they are less than 16, can even attend school. But these children are in a paradoxical situation. According to the Spanish government, they are not unaccompanied minors because they are seen as being with some adult in the country. But because this "fostering" does not mean legality, and because the government recognizes the guardianship, but does not need to make it legal in terms of bureaucracy, the Spanish police effectively turn a blind eye on such children and they cannot obtain legal residence permits. They are not sent back when they are still minors, and when they become 18 they become irregular migrants.

One social worker from the city hall social services from a city near Barcelona told me that a man reported that relatives in Morocco had sent his niece to him without telling him they were going to do so. He could not take care of her, he explained, and wanted to put her in the child protection system. The social worker called the emergency child service and explained the situation. In response, the protection system told the social worker that because this girl had a family of reference, she had to stay with the uncle or she would be sent back to Morocco. The social worker explained the situation to the uncle, who then decided to keep the girl. But, as the social worker learned, this man had an open file with the child protection system because he had abused his own children, and the local government had wanted to take custody of them to protect them.

In effect, his own children, who are legal Spanish residents and have residence permits, are treated by the Catalan government as children, as are the rest of Catalan children, but the girl who is fostered according to Moroccan custom is not. Nonetheless, she must stay in the same house and under the protection of the same man whom the government had declared unfit to take care of his own children. 
This case concerns a girl, but it also parallels what happens to boys who do not fit in the category of unaccompanied minors. They have difficulties in entering the "normal" child protection system because the government looks only at the "company" piece of their situation, avoiding the other elements of neglect. In such cases, the government tries to treat these children more as irregular migrants than as unaccompanied minors needing protection. As migrants, they just need protection if they are unaccompanied, without giving importance to other factors that should warrant a definition of them as children and as lacking protection.

\section{Conclusions}

Unaccompanied child migration from Morocco to Spain is arguably a case of globalization and of migration laws gone awry. It has an impact on Europe, in how it organizes institutions to handle these children, and on Moroccan families, in which efforts to cope with poverty through the migration of children affect ideas about the meaning of children and migration. Changing Spanish and EU laws have made migration a very different phenomenon than it was just a decade or two ago. For Moroccans, it has placed increasing emphasis on children as the bearers of this burden, and it has made it increasingly difficult for them to return, even if "successful," for anything except short visits. They are separated from their families at young ages not just by spatial distance but also by emotional distance, in that they cannot reveal the extent of their struggles. Hence, some of these children become neglected by the very systems that are charged with their protection.

In Spain, the legal and social status of Moroccan child migrants is viewed with ambivalence. On the one hand, they are minors who should be protected; on the other, they are illegal migrants who should be sent back. If they manage to reach legal Spanish territory, humanitarian laws governing child protection are supposed to take precedence, treating them as neglected children who require protection of the state as well as the international community. However, the very humanitarian ideology that claims to protect them in fact works against them, and in two ways. First, for children to qualify for state protection, the only pathway to legality that is open to them is to be seen as neglected, meaning that Moroccan families must distance themselves from their children. Second, Spanish officials, citing UN humanitarian codes that stress the family as a key human value, with its emphasis on the rights of children to live with their parents, use the idiom of family reunification as a rationale 
for sending these children back. For such children, their families, formerly supportive, now come to resent them as "failures," and refuse to accept them back as full family members. Family reunification is hardly the result.

The globalization process, while promoted by developed countries, is contradictory. It promotes free circulation of goods but also extensive control of people, making marginalized people the work force that Europe needs. In the case of the unaccompanied minors, as Suarez notes (2006: 24) in Checa (2006),

it is a disquieting phenomenon in double sense, first because the special vulnerability of the minors is evident, crossing the powerful borders between countries and continents (...) and second, because they manifest their capacity to navigate among the interstices of the contradictions of our Western society, and even the pathetic and dangerous comprise of their strategies of resistance.

These boys desire to consume Western goods, to have access to Western benefits such as holidays and medical insurance. But they desire these things not just for themselves. They know their migration could change the course of their family members' lives. Each time a boy reaches Spain under a truck or a bus, however, the failure of the ideals of human rights and the precariousness of reproduction become transparent.

The expanding EU border and concomitant tactics of exclusion have come at a high price. In Morocco, there have been enormous repercussions for marginal people who struggle to make ends meet or as they try to find access to the wealth of the EU. For their children, however, the costs are becoming even higher. The fact that under humanitarian law children must be neglected to qualify for protection generates real neglect among children, both in Europe and back in North Africa, whether unintended or intentional, to qualify a child to stay in Europe. Unaccompanied children are not seen as minors, but as unaccompanied. They need protection, as the international laws point out, but they are treated as immigrants. This is a reason why there exist two parallel lines of protection, one for the unaccompanied minors and another for other children, whether foreigners with residence permits or Catalan children. In this case we point to a gap in the system of protection that leaves out all children in irregular administrative situations who are not entirely unaccompanied. 
With the constant change in policies regulating migration and family reunification and the increasing border controls, we do not know how the next generation of potential migrants will be affected. We do not know who in the future is going to appear as the best candidate to represent a family abroad and who will be the next to feel the perverse effects of changing laws in a global world. Since the laws are changing rapidly, and the European Union is making major efforts to send back children by means of family reunification, the unaccompanied minors phenomenon will likely decrease in importance or change its character in the next years. We should start asking: What social and national category will be marginalized next?

\section{Acknowledgments}

This paper has gained much from the support by Caroline Bledsoe. The discussions with her, her comments and her editing have helped to get the paper into a better shape. Her support is greatly acknowledged. I would also like to thank the Max Planck Institute for Demographic Research for financial support of my work, and my colleagues Gunnar Andersson and Annette Fleischer and Montserrat Ventura for comments on earlier versions of this paper. The paper is based on my ongoing dissertation work which is part of the project "Transnational Vital Events" carried out by the MPIDR. 


\section{BIBLIOGRAPHY}

Bledsoe, Caroline, 1990. Transformations in Sub-saharan African marriage and fertility. Annals of the American Academy of Political and Social Science 510:115-125

Bourdieu, P. and J.C. Passeron, 1990. Reproduction in Education, Society and Culture. London: Sage Publications.

Calavita, Kitty, 2005. Immigrants at the Margins: Law, Race, and Exclusion in Southern Europe. New York: Cambridge University Press.

Capdevila, Manel and Marta Ferrer, 2003. Els menors estrangers indocumentats no acompanyats (MEINA). Justicia i Societat, num. 24. Barcelona: Centre d'Estudis Juridics i Formacio especialitzada.

CERED, 2004. Centre d'Etudes et de Recherches Démographiques. http://www.cered.hcp.ma

Checa, F., A. Olmos and J.C. Arjona (eds.), 2006. Menores Tras la Frontera, Otra Emigración que Aguarda. Barcelona: Icaria editorial.

Con RED, 2005. Rutas de pequeños sueños: Los menores migrantes no acompañados en Europa.

Report. Barcelona: Fundación Pere Tarres. Available:

http://www.peretarres.org/daphneconred/estudi/informe.html

De Genova, Nicholas, 2005. Working the Boundaries: Race, Space, and "Illegality" in Mexican Chicago.

Durham: Duke University Press.

Delgado, Manuel, 1998. Diversitat i Integració. Barcelona: Empúries.

Empez Vidal, Nuria, 2005. Menores no acompañados en situación de exclusión social. In Fernandez, Tomas, et al. (eds) Multiculturalidady Educación: Teorías, Ámbitos, Prácticas. Madrid: Alianza Editorial.

Empez Vidal, Núria. 2003. Menors No Acompanyats Estrangers Indocumentats: Una Aproximació al Fenomen. Master Thesis. Barcelona: Universitat Autònoma de Barcelona.

Ginsburg, Faye and Rayna Rapp, 1991. Politics of reproduction. Annual Review of Anthropology 20:311343.

Institut Català de l'acolliment i de l'adopció, 2005, 2006. Memòria del Departament de Benestar i

Família 2004, 2005. Available: http://www.gencat.net/benestar/xifres/mem2005/sfi.pdf and http://www.gencat.net/benestar/xifres/mem2004/sfi.pdf

Jiménez Álvarez, Mercedes, 2003. Buscar-se la Vida: Análisis Transnacional de los Procesos Migratorios de los Menores de Origen Marroqui en Andalucía. Madrid: Editorial Santa Maria. Available: http://images.indymedia.org/imc/estrecho/application/11/Buscarse_la_vida.pdf 
Jiménez Álvarez, Mercedes and Diego Lorente, 2004. Menores en las fronteras: de los retornos efectuados sin garantías a menores marroquíes y de los malos tratos sufridos. Report. Federación SOS Racismo. Available: http://www.mugak.eu/ef etp files/view/Informe menores retornados.pdf?revision id=920 2\&package $\mathrm{id}=9185$

Jiménez Álvarez, Mercedes, 2006. Donde quiebra la protección: las reagrupaciones familiares sin garantías. Taller de Estudios Internacionales Mediterráneos (UAM). Unpublished report. Konrad, Marc and Vicenta Santoja, 2005. Menores Migrantes. De los Puntos Cardinales a la Rosa de Los Vientos. Valencia: Promolibro.

Marx, Karl, 1967. Outlines of the Critique of Political Economy, Vol. II-III. New York: International Publishers.

Pérez de Lama, José, 2005. Notas sobre emergencias en el Estrecho de Gibraltar (Eurafrica). Available: http://thistuesday.org/node/118

UNICEF, Fundacio Jaume Bofill, and Junta de Andalucia, 2005. Nouveau visage de la migration les mineurs non accompagnes, analyse transnationale du phénomène migratoire des mineurs marocains vers l'Espagne. Report. Available : http://www.unicef.org/morocco/french/Etude MigrationMineurs 21nov2005.doc

Save the Children, 2004. Informe sobre la situación de los menores no acompañados en España. Documento de trabajo IV. Available: http://www.savethechildren.es/iniinterior.asp?iditem $=1237$

Scheper-Hughes, Nancy (ed), 1987. Child Survival: Anthropological Perspectives on the Treatment and Maltreatment of Children. Boston: Dordrecht.

Sindic el defensor de les persones, 2006. Informe i recomanacions: La situacio dels menors imigrats sols. Report. Available: http://www.sindic.cat/ficheros/informes/37 Situaciomenorsimmigrats.pdf

Suárez, Liliana, 2006. Un Nuevo actor migratorio: jóvenes, rutas y ritos juveniles transnacionales. In Checa, F., Olmos, A.. and J.C. Arjona, (eds.), Menores Tras la Frontera, la Otra Emigración que Aguarda: 17-50. Barcelona: Icaria.

Wolf, Eric, 1982. Europe and the People without History. Berkley, Los Angeles: California Press. 


\section{LAWS and Treaties}

Ley Orgánica 7/1985, de 1 de Julio, sobre derechos y libertades de los extranjeros en España.

Ley orgánica 8/2000, de 22 de diciembre; Ley Orgánica 4/2000 de 11 de enero, sobre derechos y libertades de los extranjeros en España y su integración social, en su redacción dada por la ley orgánica $8 / 2000$, de 22 de diciembre.

Ley orgánica 14/2003, de 20 de noviembre, de Reforma de la Ley orgánica 4/2000, de 11 de enero, sobre derechos y libertades de los extranjeros en España y su integración social, modificada por la Ley Orgánica 8/2000, de 22 de diciembre; de la Ley 7/1985, de 2 de abril, Reguladora de las Bases del Régimen Local; de la Ley 30/1992, de 26 de noviembre, de Régimen Jurídico de las Administraciones Publicas y del Procedimiento Administrativo común, y de la Ley 3/1991 de 10 de enero de competencia Desleal.

Real Decreto 2393/2004, de 30 de diciembre, por el que se aprueba el Reglamento de la Ley Orgánica 4/2000, de 11 de enero, sobre derechos y libertades de los extranjeros en España y su integración social.

Llei 8/1995, de 27 de juliol, d'atenció i protecció dels infants i adolescents , i de modificació de la Llei 37/1991, de 30 de desembre, de conformitat amb el que disposen l'article 42 de la Convenció esmentada, l'article 15 de la Llei 8/1995, també esmentada, i la Resolució 194/III, de 7 de març de 1991, del Parlament de Catalunya, sobre els drets de la infància.

Llei 37/1991, de 30 de desembre, sobre mesures de protecció dels menors desemparats i de l'adopció. (DOGC núm. 1542, de 17-01-1992)

Schengen convention (1990). Applying the Schengen agreement of 14 June 1985.

http://www.hri.org/docs/Schengen90/

Universal Declaration of Human Rights, December 10, 1948. The General Assembly of the United Nations. 
United Nations Declaration of the Rights of the Child. Proclaimed by General Assembly resolution 1386(XIV) of 20 November 1959, Convention on the Rights of the Child adopted and opened for signature, ratification and accession by General Assembly resolution 44/25 of 20 November 1989. 